\title{
シールドトンネル模型のねじり変形と破壊特性に 関する実験的研究
}

\section{川島一彦* ·杉田秀樹** $\cdot$ 加納尚史 ${ }^{* * *}$}

\begin{abstract}
シールドトンネルは，地震時の地盤の変形に伴って様々な地震力を受ける. 特に，立 坑との取付部や曲線部では, ねじりモーメントの影響が大きくなることが予想される. 本文は, シールドトンネルが权じりモーメントを受けて破壊に至るまでのメカニズムを, シールドトンネル模型の正負交番載荷実験により明らかにするものである.

Key Words : shield tunnel, seismic design, seismic deformation method, underground structures, torsional moment, failure mechanism
\end{abstract}

\section{1. まえがき}

近年，都市部では，大断面のシールドトンネルの建設 事例が増えている。我が国においては，シールドトンネ ルの設計に際して地震の影響を十分に検討しておくこと が必要とされる.しかしながら, 現在までにシールドト ンネルが大規模な地震を経験した事例はなく，地震の影 響に関する経験的な知見が十分でないこと等から，シー ルドトンネルの合理的な耐震設計法はまだ十分に整備さ れていないのが実状である.

シールドトンネルは, 地震時に地盤の変形に伴って 様々な強制変位を受ける. トンネル長手方向の変形に寄 与する地震力としては軸力が最も重要 ${ }^{1), 2}$ であるが，曲 げモーメンド)やねじりモ一メントの影響もある. 特に, 衴りモーメントについては, 1985 年のメキシコ地震 で下水道シールドトンネルが立坑との取付部で被災した 事例 ${ }^{4)}$ があり，立坑や異種構造物との取付部において影 響が大きくなることが予想される．このため，シールド トンネルの耐震性を検討するためには, 軸力や曲げモ一 メントの影響と同時に，ねじりモーメントによるトンネ ルの変形特性を十分に把握しておくことが重要となる.

シールドトンネルの站じり変形に関する研究は，これ までほとんど行われていない。メキシコ地震では, トン ネルと立坑との相対的なずれに伴ってリング継ぎボルト が破断したが，どの程度のねじりモーメントが生じたの か，また，リング継ぎボルトが破断するまでにどの程度 の站じり変形を吸収できたのか等は明らかでない.また， 被災したシールドトンネルは二次覆工を持たないため,

*正会員 工博 建設省土木研究所企画部地下開発研究官 ( ( 305 つくば市大字旭 1 番地)

**正会員 建設省土木研究所企画部建設専門官

***正会員建設省東北地方建設局酒田工事事務所鶴岡国道維 持出張所
二次覆工を有する場合にどのような変形特性を示すのか も明らかでない。このため，シールドトンネルを適切に 解析モデル化するためには，セグメント，継手，二次覆 工が複雑に組み合わされたトンネル覆工の稀じり変形と 破壊のメカニズムを明らかにしなければならない。

本報告は，上記の観点から，地震時にねじりモーメン トを受けた場合にシールドトンネルが破壊に至るまでの メカニズムを実証的に明らかにし，シールドトンネルの ねじり剛性の合理的な評価方法を開発することを目的と して，シールドトンネル模型の正負交番載荷実験を実施 した結果を報告するものである.

\section{2. 実験供試体及び載荷方法}

\section{（1）実験供試体}

実験に用いた供試体は，Fig.1に示すように，厚さ $125 \mathrm{~mm}$, 幅 $900 \mathrm{~mm}$ の RC 平板型セグメント 4 個をリ ング状に組み，これを 4 リング分だけ長手方向に連結し た Dタイプ供試体と, この内側に厚さ $200 \mathrm{~mm}$ の二次 覆工コンクリートを打設して，ジベル筋（D 10，七グメ ント 1 個あたり 12 本) により一次覆工と一体になるよ うにした E夕イプ供試体の 2 種類である.これらはい ずれも外径 $1.8 \mathrm{~m}$ の下水道用標準セグメント ${ }^{51}$ に従って 製作したものである.

二次覆工の円周方向にはリング筋として D 13 を 12 本 (4 リング分，鉄筋比 $0.22 \%)$ ，長手方向には供試体の 全長にわたってD 13 を 16 本（鉄筋比 $0.32 \%$ ）を配置 した.

リング継手及びセグメント継手の構造としては Fig.2 に示す構造を用いた. ともに，面板に溶接された D 10 及び D 13 のアンカー鉄筋 (長さ $300 \mathrm{~mm}$ ) によってセグ メントに定着されている. 継ぎボルトには M 20 を用い, 降伏強度の $80 \%$ である $4.7 \mathrm{tf}(46.1 \mathrm{kN})$ を目標に締め 付けた。 


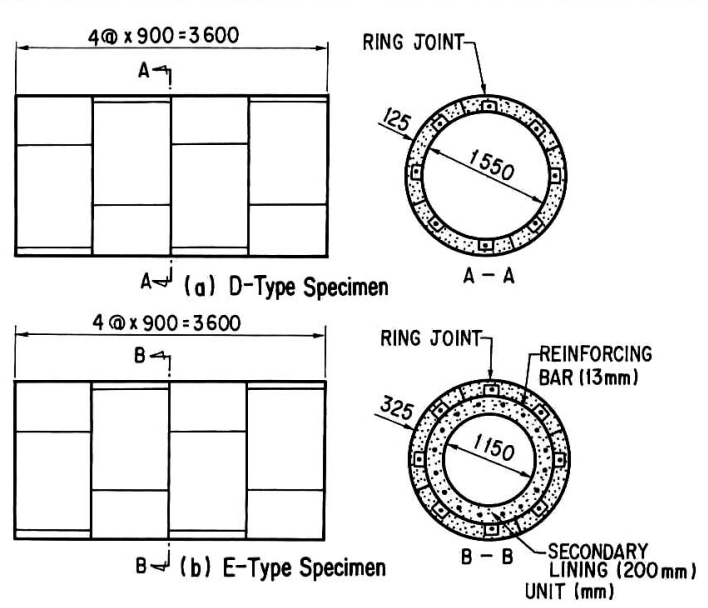

Table 1 Average Strength $\left(\mathrm{kgf} / \mathrm{cm}^{2}\right)$ of Concrete

\begin{tabular}{|c|c|l|l|}
\hline \multicolumn{2}{|c|}{ SPECIMEN } & $\begin{array}{l}\text { FOR } \\
\text { COMPRESSION }\end{array}$ & $\begin{array}{l}\text { FOR } \\
\text { TENSION }\end{array}$ \\
\hline \multirow{2}{*}{ D-TYPE (SEGMENT) } & $\begin{array}{l}580.9 \\
(57.0 \mathrm{MPa})\end{array}$ & $\begin{array}{l}46.9 \\
(4.6 \mathrm{MPa})\end{array}$ \\
\hline \multirow{4}{*}{ E-TYPE } & SEGMENT & $\begin{array}{l}610.8 \\
(59.9 \mathrm{MPa})\end{array}$ & $\begin{array}{l}49.6 \\
\text { (4.9MPa) }\end{array}$ \\
\cline { 2 - 4 } & SECONDARY & $\begin{array}{l}289.3 \\
(28.4 \mathrm{MPa})\end{array}$ & $\begin{array}{l}26.2 \\
(2.6 \mathrm{MPa})\end{array}$ \\
\hline
\end{tabular}

Table 2 Average Strength $\left(\mathrm{kgf} / \mathrm{cm}^{2}\right)$ of Reinforcing Bar

Fig.1 Specimens Adopted for Loading Tests
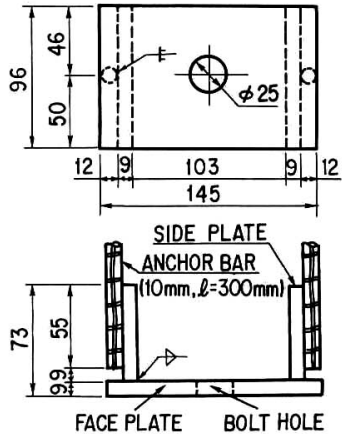

(a) Ring Joint
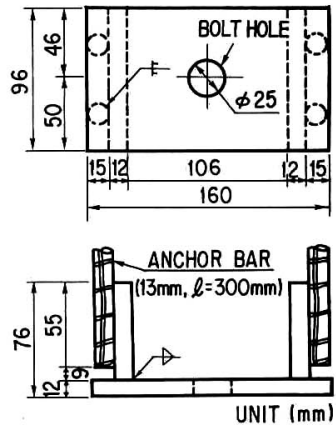

(b) Segment Joint

Fig.2 Ring Joint and Segment Joint

コンクリートの強度を示すと Table 1 の通りである.

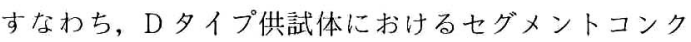
リートの平均強度は引張，圧縮に対してそれぞれ 46.9 $\mathrm{kgf} / \mathrm{cm}^{2}(4.6 \mathrm{MPa}), 580.9 \mathrm{kgf} / \mathrm{cm}^{2}(57.0 \mathrm{MPa})$, また E夕イプ供武体におけるセグメントコンクリート及び 二次覆工コンクリートの平均強度は引張, 王縮に対して それぞれ $49.6 \mathrm{kgf} / \mathrm{cm}^{2}(4.9 \mathrm{MPa}), 610.8 \mathrm{kgf} / \mathrm{cm}^{2}(59.9$ $\mathrm{MPa})$, 及び $26.2 \mathrm{kgf} / \mathrm{cm}^{2}(2.6 \mathrm{MPa}), 289.3 \mathrm{kgf} / \mathrm{cm}^{2}$ (28. $4 \mathrm{MPa}$ ) である. 鉄筋の平均降伏強度は Table 2 に 示すようにD 10, D 13 に対してそれぞれ $3916 \mathrm{kgf} / \mathrm{cm}^{2}$ (384. $0 \mathrm{MPa}), 3552 \mathrm{kgf} / \mathrm{cm}^{2}(348.3 \mathrm{MPa})$ である.ま た，平均破断強度はD 10，D 13 に対してそれぞれ 5487 $\mathrm{kgf} / \mathrm{cm}^{2}(538.1 \mathrm{MPa}), 5625 \mathrm{kgf} / \mathrm{cm}^{2}(551.6 \mathrm{MPa})$ て ある。

\section{（2）載荷方法}

Photo 1 は載荷方法を示したものである，供試体は架 台を介して, 一端を反力床に, 他端を載荷板に固定した. 二次覆工があるEタイプ供試体では，一次覆工と二次覆 工の両方を架台及び載荷板に固定し，供試体長手方向に

\begin{tabular}{|c|l|l|}
\hline DIAMETER & YIELDING & RUPTURE \\
\hline $10 \mathrm{~mm}$ & $\begin{array}{l}3916 \\
(384.0 \mathrm{MPa})\end{array}$ & $\begin{array}{l}5487 \\
(538.1 \mathrm{MPa})\end{array}$ \\
\hline $13 \mathrm{~mm}$ & $\begin{array}{l}3552 \\
\text { (348.3MPa) }\end{array}$ & $\begin{array}{l}5625 \\
(551.6 \mathrm{MPa})\end{array}$ \\
\hline
\end{tabular}

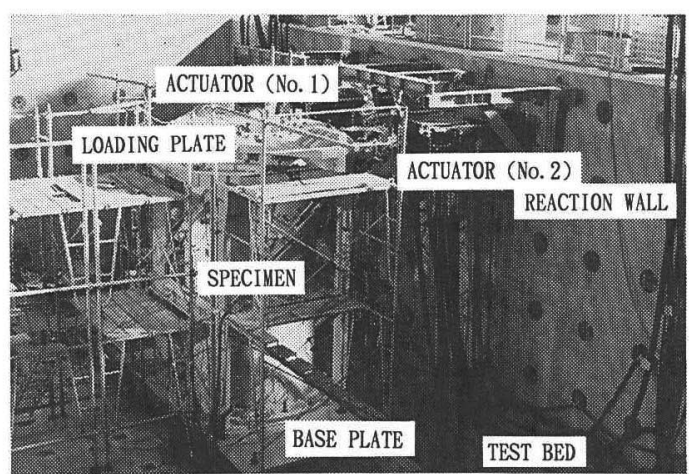

Photo 1 Experimental Set-up
同一の変形を与えることとした．これは，本供武体のよ うに，覆工問をジベル筋で連結しているシールドトンネ ルでは，一次覆工と二次覆工はトンネル長手方向に一体 として変形すると考えられるためである.

載荷板の両端にはそれぞれ動的加振機を取り付け, 2 台の動的加振機をディジタル制御で操作することによ り，鉛直軸まわりのねじりモーメントを Fig.3に示すパ ターンで供試体に作用させた、权じりモーメントの載荷 に際しては，2台の動的加振機の載荷軸力が，符号が逆 で,同一の絶対値となるように調整し,純粋な水じりモ一 メントのみを載荷するように留意した。 ねじりモーメン トの正負については，供試体の上方から見て左回りの場 合を正の棵じりモ一メントとし, 逆に右回りの場合を負 のねじりモーメントと定義した. 本文で用いる載荷ルー プの定義は Fig.3に示す通りであり，ねじりモーメント を珈ら増加させ，再び 0 にもよ゙すまでを 1 ループよし ている.

本供試体にはリング接合面（セグメントリングどうし がリング継手によって接合されている面.これに対して， 

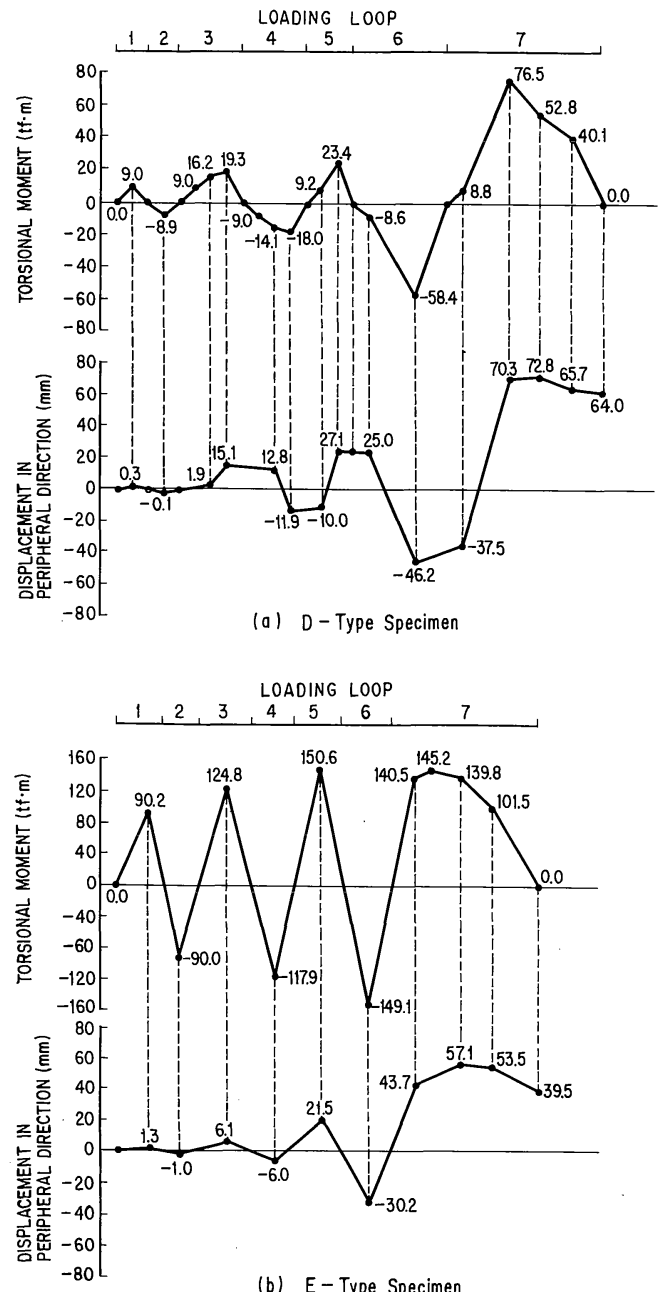

Fig.3 Loading Hysteresis Loop

セグメントどうしがセグメント継手によって接合されて いる面をセグメント接合面と呼んで区別する）が 3 箇所 あるが，これを反力床に近い方から，それぞれ JT 1 , JT 2, JT 3 と呼ぶこととする.

本実験ではねじりモーメントによる供試体の変形に着 目しているが，供試体長手方向にも載荷板の重量約 $5 \mathrm{tf}$ $(49.0 \mathrm{kN})$ が軸力として作用している.この軸力によっ てセグメントに発生する軸応力度は, D タイプ供試体

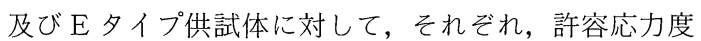
の約 $0.7 \%$ 及び約 $0.3 \%$ に相当する.

\section{D タイプ供試体の変形及び破壊特性}

\section{（1）供試体の変形及び破壊状況}

D タイプ供試体の最終的な破壊状況を Fig.4 に示す. 二次覆工のないDタイプ供試体では, リング継手及び セグメント継手を中心としてセグメントの内外面に斜め 引張クラックが生じ，最終的にリング継ぎボルト及びリ

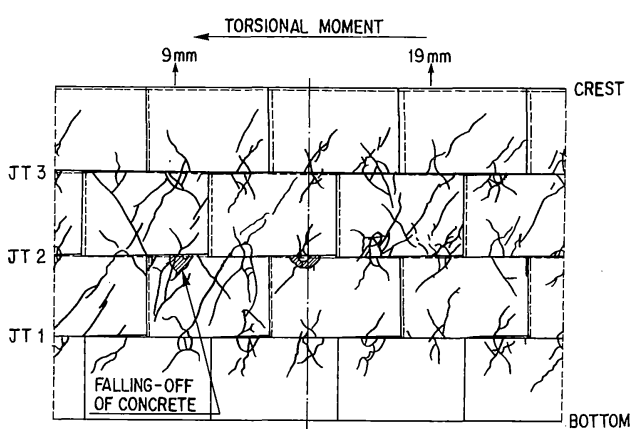

(a) Outside of Segment

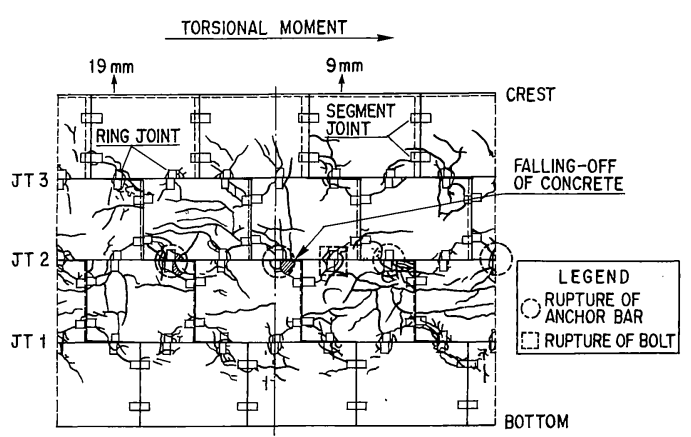

(b) Inside of Segment

Fig.4 Failure Mode of D-type Specimen

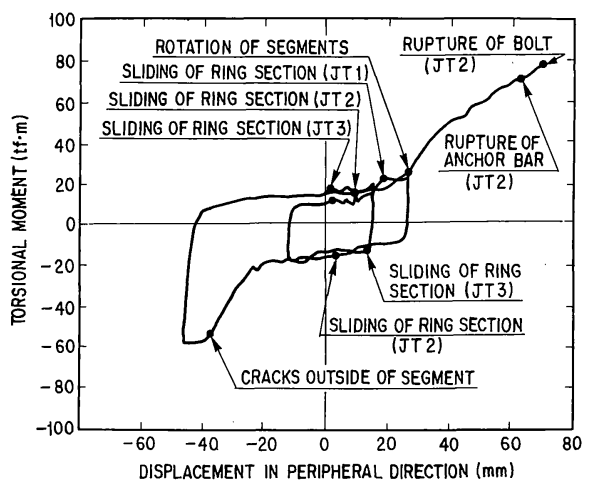

Fig.5 Loading Hysteresis of D-type Specimen

ング継手のアンカー鉄筋が破断することにより破壊に 至った.

供試体天端位置における供試体の円周方向変形量と載 荷放じりモーメントの履歴を示すと Fig.5 の通りであ る.これによれば，供試体の損傷は概ね次の順番で生じ る.

(1)載荷ねじりモーメントが $16.2 \mathrm{tf} \cdot \mathrm{m}(158.9 \mathrm{kN} \cdot \mathrm{m})$, 円周方向変形量が $1.9 \mathrm{~mm}$ に達した段階 (3ループめ) で, リング接合面 JT 3 でセグメントリング間の滑りが 生じた.さらに円周方向変形量が $8.9 \mathrm{~mm}$ に達した段階 で，リング接合面 JT 2 でも滑りが生じた. この後, ね じりモーメントを増加しなくてもリング接合面 JT 2 及 


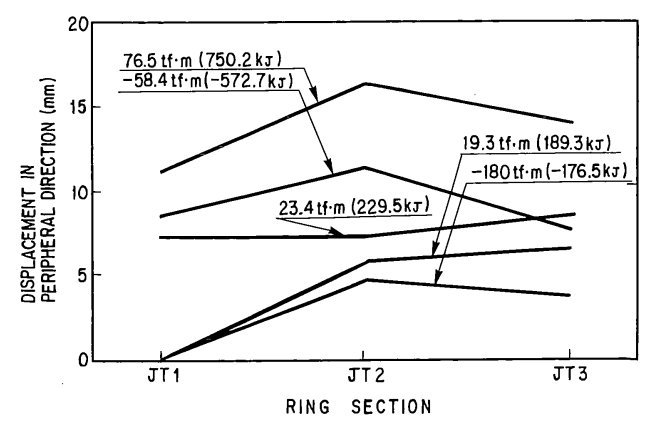

Fig.6 Displacement in Peripheral Direction Developed at Ring Section (D-type Specimen)

びJT 3 が滑り続けたが，円周方向変形量が $15.1 \mathrm{~mm}$ に 達すると，ねじりモーメントを $19.3 \mathrm{tf} \cdot \mathrm{m}(189.3 \mathrm{kN} \cdot \mathrm{m})$ まで増加しても滑らなくなった。

(2)載荷秝じりモーメントがー $14.1 \mathrm{tf} \cdot \mathrm{m}(-138.3$ $\mathrm{kN} \cdot \mathrm{m})$, 円周方向変形量が $12.8 \mathrm{~mm}$ に達した段階 $(4$ ループめ) で, リング接合面 JT 3 で滑りが生じた。さ らに円周方向変形量が $2.4 \mathrm{~mm}$ に達した段階で, リン グ接合面 JT 2 でも滑りが生じた.この後，リング接合 面 JT 2 及び JT 3 が滑り続けたが，円周方向変形量が $-11.9 \mathrm{~mm}$ になるとねじりモーメントをー $18.0 \mathrm{tf} \cdot \mathrm{m}$ $(-176.5 \mathrm{kN} \cdot \mathrm{m})$ まで増加させても滑らなくなった.

(3)載荷ねじりモーメントが $23.0 \mathrm{tf} \cdot \mathrm{m}(225.6 \mathrm{kN} \cdot \mathrm{m})$, 円周方向変形量が $18.4 \mathrm{~mm}$ に達した段階 (5ループめ) で，リング接合面 JT 1 でも滑りが生じた。权じりモ一 メントを増加させると，リング接合面 JT 2 で，リング 継手から隣接するセグメント継手に向かう斜め引張ク ラックが生じた。

(4)載荷ねじりモーメントがー $52.5 \mathrm{tf} \cdot \mathrm{m}(-514.8$ $\mathrm{kN} \cdot \mathrm{m})$, 円周方向変形量がー $36.8 \mathrm{~mm}$ に達した段階 $(6$ ループめ) で，リング接合面 JT 2 のリング継手位置で セグメントの外周面にクラックが生じた。 さらにねじり モ一メントを増加させると, リング接合面 JT 1 及び JT 3 でも, セグメント内面及び外周面のクラックが発生し た。

(5)載荷袢じりモーメントが $69.0 \mathrm{tf} \cdot \mathrm{m}(676.7 \mathrm{kN} \cdot \mathrm{m})$, 円周方向変形量が $61.0 \mathrm{~mm}$ に達した段階 (7ループめ) で，リング接合面 JT 2 において 4 箇所のリング継手の アンカー鉄筋が相次いで破断した。さらに，載荷ねじり モーメントが $64.6 \mathrm{tf} \cdot \mathrm{m}(633.5 \mathrm{kN} \cdot \mathrm{m})$, 円周方向変形 量が $71.5 \mathrm{~mm}$ に達した段階で，リング接合面 JT 2 にお けるリング継ぎボルトが 1 箇所で破断した。

Fig.5 の横軸は，供試体全長を通じて生じた円周方向 変形量であるが，3 箇所のリング接合面ごとによ゙のよう に円周方向の変形が生じたかを示すと Fig.6 の通りであ る.これによれば，3箇所全てのリング接合面でセグメ ントリング間の滑りが生じた 5 ループめ（載荷ねじり

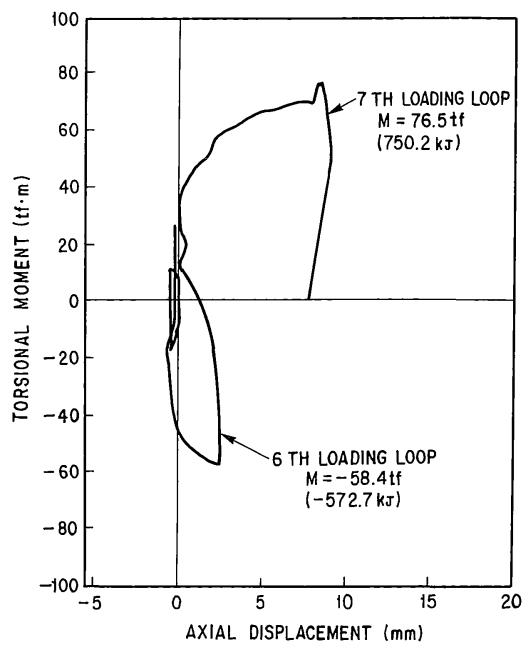

Fig.7 Hysteresis Loop of Axial Displacement (D-type Specimen)

モーメント $M=23.4 \mathrm{tf} \cdot \mathrm{m}(229.5 \mathrm{kN} \cdot \mathrm{m}))$ までは 3 箇 所ともほぼ同じ変形が生じるが, 上記(4)(6ループめ, $M=-52.5 \mathrm{tf} \cdot \mathrm{m}(-514.8 \mathrm{kN} \cdot \mathrm{m}))$ 以降になると, 最初 にセグメントの外面にクラックを生じたリング接合面 JT 2 で変形量の増加が大きいことがわかる.

また，衫じりモーメントの載荷に伴う供試体長手方向 の変形量を示すと Fig.7 の通りである.これによれば, 供試体長手方向変形量は，リング接合面に滑りが生じた 5 ループめまではほとんど生じておらず，セグメントの 内外面でクラックが生じた 6 ループめ以降で, 急激に増 加することがわかる.

以上の結果から, 供試体の破壊に関して以下の点が指 摘される.

1）供試体に加えられたねじり変形は，まずリング接 合面でセグメントリング間が滑ることにより吸収され る.さらに変形が大きくなってリング接合面の滑りだけ で吸収できなくなると，セグメントに斜め引張クラック が生じる.これは，個々のセグメントが面内方向に回転 しようとしたことを示すものである. すなわち，七グメ ントはリング継手及びセグメント継手により回転を拘束 されているため, せん断変形を強制され, 斜め引張クラッ クが生じることになる.

2）リング継手の破壊は，最初にセグメントの内外面 にクラックを生じたリング接合面 JT 2 に集中して発生 した．他のリング接合面では，リング継手の周辺でセグ メントの内外面にクラックが発生しただけに留まった. このように，一次覆工のみのシールドトンネルでは，あ る特定のリング接合面で耐力が減少する程度の損傷が生 じると，これを上回る載荷力を受けた場合に，そのリン グ接合面においてのみ損傷が集中する.このような損傷 特性は，正負交番の軸力及び曲げモーメントを受ける 


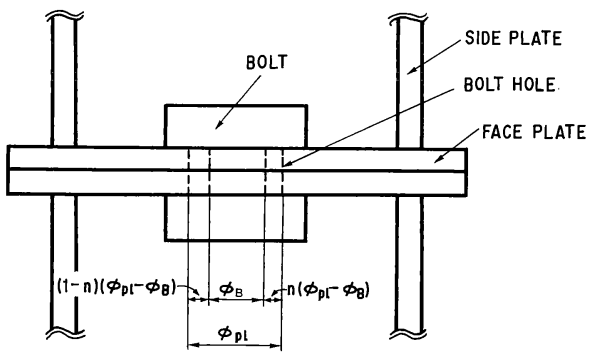

(a) Prior to Sliding of Ring Section

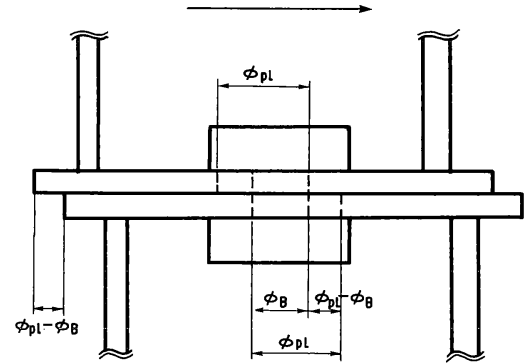

(b) After Sliding of Ring Section

Fig.8 Sliding Developed at Ring Section

シールドトンネルの損傷特性 ${ }^{1)-31}$ と一致する.

3） 1 箇所のリング接合面が滑ることにより吸収でき る円周方向の変形量 $\delta_{J T}$ は, Fig. 8 に示すように, 次式 で算出することができる.

$\delta_{J T}=\phi_{p l}-\phi_{B}$

ここに， $\phi_{p l}$ はリング継手金具面板に開けられたボル 卜孔の直径， $\phi_{B}$ はリング継ぎボルトの軸部の直径であ る. 本供試体では，1箇所のリング接合面が滑ることに より吸収した円周方向変形量は平均約 $9 \mathrm{~mm}$ であり; 式 (1) により計算される $\delta_{J T}=7.7 \mathrm{~mm}$ に比べてわずか に大きい。これは，3 箇所のリング接合面で順番に滑り が生じる段階で，継手金具面板のボルト孔に継ぎボルト がわずかにくい込んだためである.

4）リング接合面の滑り摩擦係数 $\mu_{J T}$ は, 次式で算出 できる.

$\mu_{J T}=\frac{M_{J T}}{r_{B}\left(W+W_{0}\right)}$

ここに， $M_{J T}$ は当該りング接合面で滑りが生じた時 の載荷ねじりモーメント， $r_{B}$ はボルトサークル半径, $W$ は当該リング接合面より上部の供試体の重量， $W_{0}$ は 当該りング接合面に位置するリング継ぎボルトの初期軸 力の合計，である。式（2）により，リング接合面 JT 1 , JT 2 及び JT 3 における摩擦係数を算出すると，そ
Table 3 Deformation and Strength of Spesimens (a) D-Type Specimen

\begin{tabular}{|c|c|c|c|c|c|c|}
\hline \multirow{2}{*}{ PROGRESS OF FAILURE } & \multirow[t]{2}{*}{$\begin{array}{l}\text { RING } \\
\text { SECTION }\end{array}$} & \multirow{2}{*}{$\begin{array}{l}\text { TORSIONAL } \\
\text { MOMENT } \\
(\mathrm{t} f \cdot \mathrm{m})\end{array}$} & \multirow{2}{*}{$\begin{array}{l}\text { DISPLACEMENT } \\
\text { IN PERIPHERAL } \\
\text { DIRECTION } \\
\text { (mm) }\end{array}$} & \multicolumn{3}{|c|}{$\begin{array}{l}\text { DISPLACEMENT DEVELOPED } \\
\text { AT RING SECTION }(\mathrm{mm})\end{array}$} \\
\hline & & & & JT1 & JT2 & JT3 \\
\hline \multirow{3}{*}{$\begin{array}{l}\text { SLIDING AT RING } \\
\text { SECTIONS }\end{array}$} & JT3 & $\begin{array}{l}16.2 \\
(158.9 \mathrm{~kJ})\end{array}$ & 0.3 & 0.1 & 0.0 & 0.0 \\
\hline & JT2 & $\begin{array}{l}16.2 \\
(158.9 \mathrm{~kJ})\end{array}$ & 8.9 & 0.3 & 0.8 & 6.2 \\
\hline & JT1 & $\begin{array}{l}23.0 \\
(225.6 \mathrm{~kJ})\end{array}$ & 18.4 & 0.9 & 7.0 & 8.7 \\
\hline $\begin{array}{l}\text { CRACKS OUTSIDE OF } \\
\text { SEGMENT }\end{array}$ & JT2 & $\begin{array}{l}-52.5 \\
(-514.8 \mathrm{~kJ})\end{array}$ & -36.9 & -9.0 & -10.7 & -5.6 \\
\hline $\begin{array}{l}\text { RUPTURE OF ANCHOR } \\
\text { BARS }\end{array}$ & JT2 & $\begin{array}{l}69.0 \\
(676.7 \mathrm{~kJ})\end{array}$ & 60.8 & 10.0 & 16.2 & 11.9 \\
\hline $\begin{array}{l}\text { MAXIMUM TORSIONAL } \\
\text { MOMENT }\end{array}$ & ........... & $\begin{array}{l}76.5 \\
(750.2 \mathrm{~kJ})\end{array}$ & 70.3 & 11.3 & 20.1 & 11.9 \\
\hline FINAL FAILURE & ............ & $\begin{array}{l}64.6 \\
(633.5 \mathrm{~kJ})\end{array}$ & 71.5 & 11.5 & 20.3 & 14.4 \\
\hline
\end{tabular}

(b) E-Type Specimen

\begin{tabular}{|c|c|c|c|c|c|c|}
\hline \multirow{2}{*}{ PROGRESS OF FAILURE } & \multirow[t]{2}{*}{$\begin{array}{l}\text { RING } \\
\text { SECTION }\end{array}$} & \multirow{2}{*}{$\begin{array}{l}\text { TORSIONAL } \\
\text { MOMENT } \\
(\mathrm{t} \cdot \mathrm{m})\end{array}$} & \multirow{2}{*}{$\begin{array}{l}\text { DISPLACEMENT } \\
\text { IN PERIPHERAL } \\
\text { DIRECTION } \\
(\mathrm{mm})\end{array}$} & \multicolumn{3}{|c|}{$\begin{array}{l}\text { DISPLACEMENT DEVELOPED } \\
\text { AT RING SECTION (mm) }\end{array}$} \\
\hline & & & & JT1 & JT2 & JT3 \\
\hline $\begin{array}{l}\text { CRACKS AT SEGMENT } \\
\text { AND SECOND LINING }\end{array}$ & $\ldots . . . .$. & $\begin{array}{l}116.8 \\
(1145.4 \mathrm{~kJ})\end{array}$ & 2.9 & 0.4 & 0.3 & 0.6 \\
\hline $\begin{array}{l}\text { SEPARATION OF } \\
\text { SEGMENTS }\end{array}$ & JT2 & $\begin{array}{l}128.0 \\
(1255.3 \mathrm{~kJ})\end{array}$ & 9.8 & 1.8 & 1.4 & 2.1 \\
\hline $\begin{array}{l}\text { MAXIMUM TORSIONAL } \\
\text { MOMENT }\end{array}$ & $\ldots . .$. & $\begin{array}{l}150.6 \\
(1476.9 \mathrm{~kJ})\end{array}$ & 21.5 & 3.2 & 3.7 & 4.3 \\
\hline FINAL FAILURE & 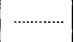 & $\begin{array}{l}140.5 \\
(1377.8 \mathrm{~kJ})\end{array}$ & 38.6 & 4.6 & 9.0 & 9.5 \\
\hline
\end{tabular}

れぞれ $0.67,0.51$ 及び 0.65 となり，平均的に見ると 0.6 程度の值である.

5）1）に示した理由により，供試体の損傷はリング 継手の周辺に留まらず，セグメント本体及びセグメント 継手にも生じた.これは, 正負交番の軸力あるいは曲げ モーメントを受けるシールドトンネルの損傷が, リング 接合面においてのみ生じる ${ }^{21,3)}$ の大大きく異なる. セグ メントの斜め引張クラックを防ぐためには, リング接合. 面の滑り変形性能を高めることにより, セグメントの回 転変形の発生を遅らせることが有効である.

Dタイプ供試体の変形性能及び耐力をまとめると Table 3 の通りである. なお，ここには後述するEタイ プ供試体の結果も併せて示している.

（2）リング継手の変形特性

アンカー鉄筋及び継ぎボルトの破断が生じたリング接 合面 JT.2について，リング継手の損傷状況を示すと Fig.9の通りである.これによれば，以下の点が指摘さ れる.

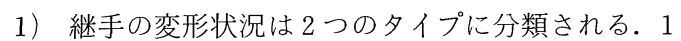
つめは, Fig.9（a）に示すように, 向かい合った継手 金具がせん断変形と引張変形を同時に生じる夕イプであ る.この夕イプでは継手金具面板が “く”の字状に変形 している. 2つめは, Fig.9 (b) に示すように, 向か い合った継手金具がせん断変形だけを生じているタイプ である.アンカー鉄筋の破断は全て 1 つめタイプの継

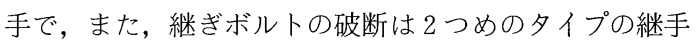




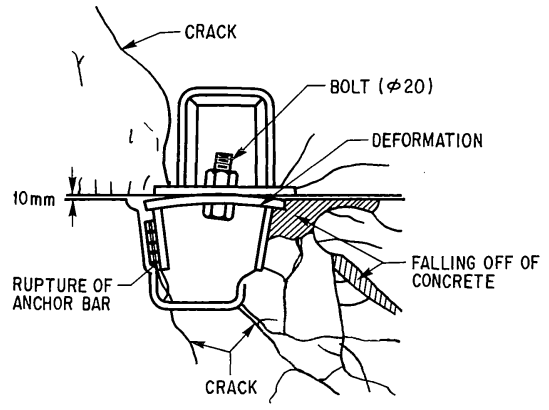

(a) Ring Joint Subjected to Shear Force and Axial Force

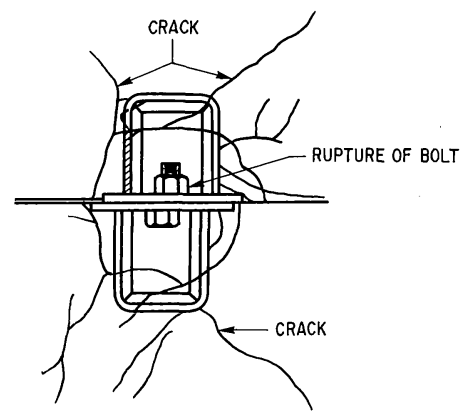

(b) Ring Joint Subjected to Shear Force

Fig.9 Failure Mode of Ring Joint (D-type Specimen)

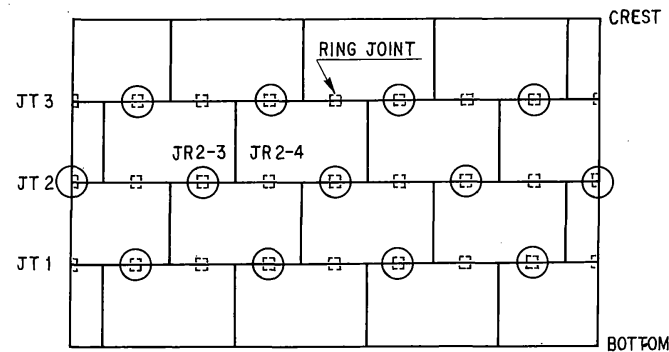

(1]) RING JOINT SUBJECTED TO

Fig.10 Locations of Ring Joints Subjected to Shear Force and Axial Force

で，それぞれ生じる.

2) $2 つ$ 夕イプの変形を生じたリング継手は, Fig.10に示すように，同一のリング接合面内では交互 に現われる．これは，セグメントの回転変形によるもの である．セグメントが回転する方向はねじりモーメント の載荷方向に応じて変化するが，七グメントの同一辺上 にある 2 つリング継手のうち，向かい合うセグメント に押しつけられる継手にはせん断変形が，また，向かい 合うセグメントから離される継手にはせん断変形と引張 変形が同時に生じることになる。

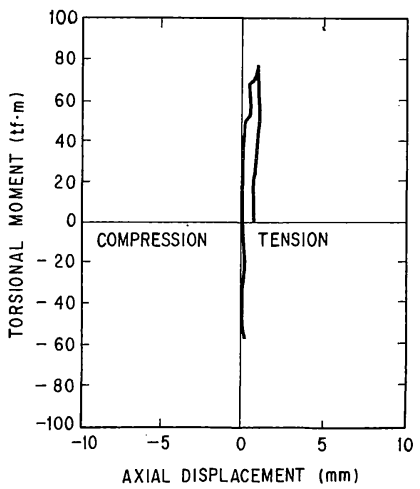

(a) Segment Joint subjected to Tension Force

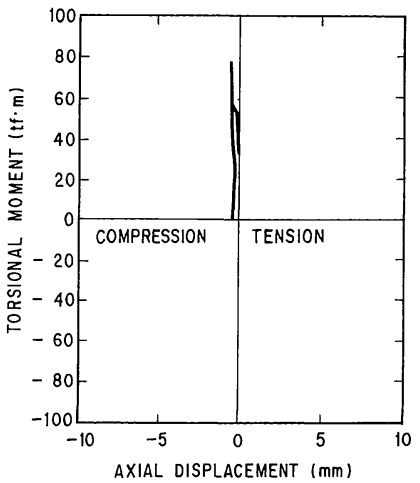

(b) Segment Joint subjected to Compression Force

Fig.11 Axial Displacement Developed at Segment Joint

3）アンカー鉄筋は定着板の端部位置で破断してい る.これは，継手金具面板が “く”の字状に変形し，定 着板がボルトボックス内に折曲げられた結果, アンカー 鉄筋には引張力と曲げモーメントが同時に作用したため である。このような継手の破壊特性は，正負交番の軸力 及び曲げモーメントを受けるシールドトンネルの損傷特 性と一致する21,3). したがって，ねじりモーメントを受 ける場合でも，継手金具面板の変形を抑えることが，ア ンカー鉄筋の破断を遅らせ，トンネルの耐力を向上する 上で有効である。

\section{（３）セグメント継手の変形特性}

セグメントの同一辺上に位置する 2 箇所のセグメント 継手に着目して, 継手の目開き量と載荷礼じりモーメン トの履歴を示すと Fig.11の通りである.これによれば, 正のねじりモーメントを載荷した場合に，一方は目開き を生じ，もう一方は向かい合うセグメントに押しつけら れる等，セグメントの回転変形の影響が認められる。た だし，セグメント継手ではアンカ一鉄筋の本数が 4 本で あること，また，継手金具面板が厚いこと等により，リ ング継手に比べると目開き量は小さい. 


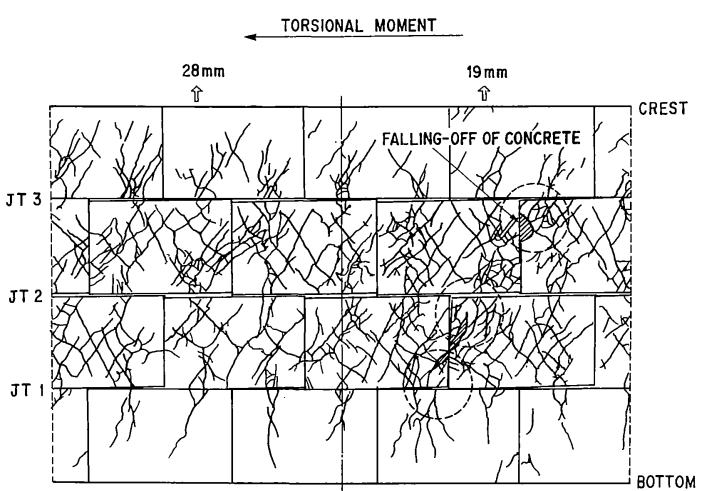

(a) Segment

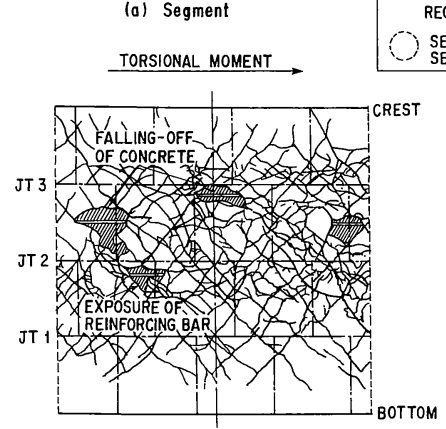

(b) Secondary Lining

Fig.12 Failure Mode of E-type Specimen

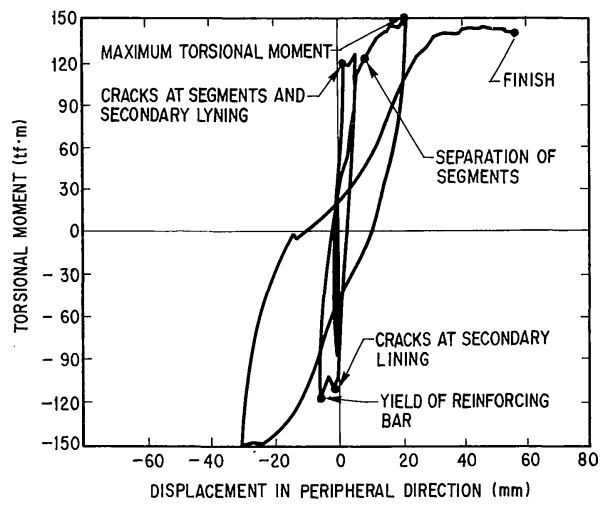

Fig.13 Loading Hysteresis of E-type Specimen

\section{4. $E$ タイプ供試体の変形及び破壊特性}

\section{（1）供試体の変形及び破壊状況}

Eタイプ供試体の最終的な破壊状況を示すと Fig.12 の通りである.二次覆工を有するE夕イプ供試体では, セグメント及び二次覆工の両方に, 無数の斜め引張ク ラックが交差するように生じた．特に二次覆工の損傷は 著しく,コンクリートが剝落して内部の二次覆工鉄筋が 露出した。 なお, 本供試体では, 損傷の進展に伴って供 試体の自立性が失われる恐れが生じたため, 継手の破壊 や二次覆工鉄筋の破断が生じる前に載荷を終了した.

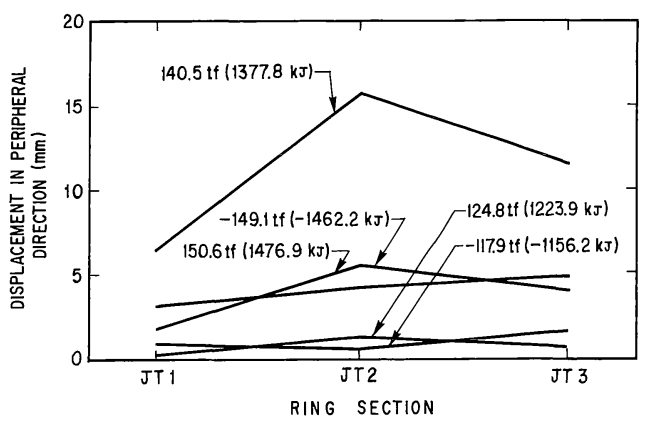

Fig.14 Displacement in Peripheral Direction Developed at Ring Section (E-type Specimen)

供試体天端位置における供試体の円周方向変形量と載 荷齐じりモーメントの履歴を示すとFig.13 の通りであ る.これによれば，供試体の損傷は，以下の順番で生じ た。

(1)載荷ねじりモーメントが $116.8 \mathrm{tf} \cdot \mathrm{m}(1145.4$ $\mathrm{kN} \cdot \mathrm{m}$ ), 円周方向変形量が $2.9 \mathrm{~mm}$ に達した段階 (3ルー プめ) で，2 3 リングに跨る二次覆工の斜め引張クラッ クが生じた。 セグメントには，リング継手の定着板の端 部からリング接合面に向かうクラックが生じた.

(2)載荷格じりモーメントがー105.2 tf·m $(-1031.7$ $\mathrm{kN} \cdot \mathrm{m})$, 円周方向変形量が $-2.8 \mathrm{~mm}$ に達した段階 $(4$ ループめ) で，(1)で生じたのと交差する斜め引張クラッ クが二次覆工に生じた。この段階までに，全てのリング 継手で定着板の端部からリング接合面に向かうクラック が生じた.

(3) 5 ループめの載荷に伴い, 各々のセグメントの中央 部で亀甲状のクラックが生じた。載荷ねじりモーメント が $128.0 \mathrm{tf} \cdot \mathrm{m}(1255.3 \mathrm{kN} \cdot \mathrm{m})$, 円周方向変形量が 9.8 $\mathrm{mm}$ となった段階で，亀甲状のクラックがリング接合面 とセグメント接合面に達し，リング接合面 JT 2 に接す る箇所でセグメントの分断が生じた．さらに荷重を増加 すると，それぞれリング接合面 JT 1 及び JT 3 に接する 䇢所でセグメントの分断が生じた.

(4)載荷放じりモーメントが $140.5 \mathrm{tf} \cdot \mathrm{m}(1377.8 \mathrm{kN}$. $\mathrm{m})$, 円周方向変形量が $38.6 \mathrm{tf} \cdot \mathrm{m}$ に達した段階（7ルー プめ）で，二次覆工コンクリートが剝落して二次覆工鉄 筋が露出した。 セグメントでも，コンクリートが剥落し てセグメント継手のアンカー鉄筋が露出した.

供試体円周方向の変形が，3 籄所のリング接合面ごよ によ゙のように分布しているかを示すとFig.14の通りで ある。これによれば，4ループめ（載荷㸚じりモーメン ト $M=-117.9 \mathrm{tf} \cdot \mathrm{m}(-1156.2 \mathrm{kN} \cdot \mathrm{m}))$ までは, 円周 方向の変形は JT 1, JT 2, JT 3 の間で同程度であるが, これ以降の載荷になると最初にセグメントの分断が生じ たリング接合面 JT 2 で増加することがわかる.

ねじりモーメントの載荷に伴う供試体長手方向の変形 


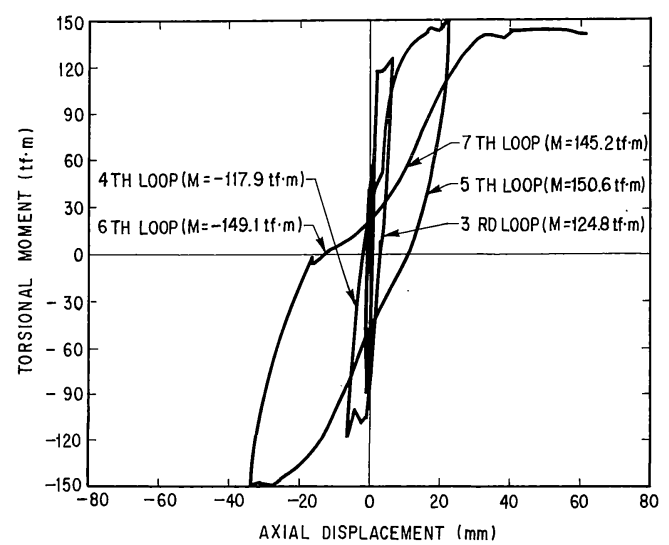

Fig.15 Hysteresis Loop of Axial Displacement (E-type Specimen)

量を示すと Fig.15の通りである.これによれば，供試 体長手方向の変形はすでに載荷の初期段階から生じてお り，Dタイプ供試体ではリング接合面に滑りが生じて いる間は供試体長手方向変形が全く生じなかったのと大 きく異なる。

以上が $\mathrm{E}$ タイプ供試体の破壊の進展状況である.こ れを D タイプ供試体と比較すると, 以下の点が指摘さ れる.

1）二次覆工が打設され, 一次覆工と二次覆工がジベ ル筋で連結されるシールドトンネルでは, 一次覆工のみ のシールドトンネルのようにリング接合面の滑りは生じ ない。これは，ジベル筋により，七グメントと二次覆工 の変形が互いに拘束されるためである.

2) 供試体の最終的な破壊は，リング継手の破壊や二 次覆工鉄筋の破断が生じる前に，セグメント及び二次覆 工がせん断破壊することにより生じた。これは，D夕 イプ供試体において, 損傷がリング接合面のみに集中し, セグメントにはほとんど損傷が生じなかったのと大きく 異なる．軸力及び曲げモーメントを受けるシールドトン ネルやねじりモーメントを受ける一次覆工のみのシール ドトンネルでは, リング継手の耐震性を向上することが 重要であるが，二次覆工を有するシールドトンネルがね じりモ一メントを受ける場合には，セグメント及び二次 覆工のせん断耐力を向上することが重要となる.

3）セグメントの分断が生じるまでは, 載荷に伴うリ ング接合面の円周方向変形量は, 3 箇所のリング接合面 でほほ均等である。これは，Dタイプ供試体において， ある一つのリング接合面でセグメントの外面にクラック が生じた途端に，このリング接合面に損傷が集中したの と大きく異なる.

4) Eタイプ供試体の耐力及び変形性能は Table 3 に 示した通りである. D タイプ供試体と $\mathrm{E}$ タイプ供試体 では破壊特性が大きく異なるため, 同一の損傷状態に達

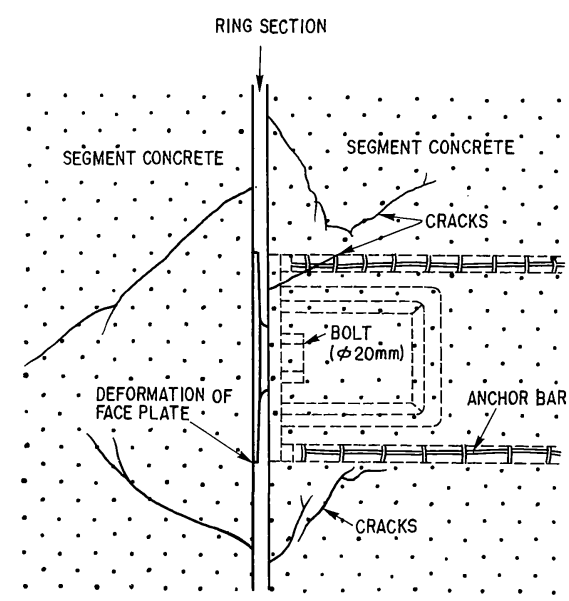

Fig.16 Failure Mode of Ring Joint (E-type Specimen)

する時の供試体の耐力及び変形性能を比較することは難 しい. しかし，Dタイプ供試体でセグメントの外面に クラックが生じ始めた時の円周方向変形量に着目する と, Eタイプ供試体ではすでに，セグメントの分断や 二次覆工の斜め引張クラックが著しく進展している.こ れは，一次覆工のみのシールドトンネルの方が，二次覆 工を有するシールドトンネルに比べて, 大きなねじり変 形性能を有することを示すものである.これは，軸力ゃ 曲げモーメントを受けるシールドトンネルで, 二次覆工 を有する場合の方が一次覆工だけの場合に比べて大きな 変形性能を有するのと大きく異なる.

\section{（2）リング継手の変形特性}

E夕イプ供試体では二次覆工があるため, 継手の変 形状況を明らかにすることができない．比較的大きな目 開きを生じたりング接合面 JT 2 について, リング継手 の変形状況をセグメントの外側から観察するとFig.16 の通りである.これによれば，継手金具面板の変形がボ ルトボックス内のコンクリートにより拘束される結果, ボルト位置を中心とする円錐台状に変形している. D タイプ供試体のアンカー鉄筋は, 定着板がボルトボック ス内に折曲げられた結果, 引張力に加えて曲げを受けて 破断していることを考えれば，たとえ二次覆工を設けな い場合でも，ボルトボックス内にコンクリートを充填す ることが, アンカ一鉄筋の破断を遅らせ, トンネルの変 形性能を向上する上で有効である.

\section{5. 結 論}

ねじりモーメントを受けるシールドトンネルの覆工剛 性及び変形特性を把握することを目的として, リングを 組んだシールドトンネル模型を用いて正負交番のねじり 載荷実験を行った. 本実験により得られた結果をまとめ ると, 以下の通りである. 
（1）一次覆工のみのD タイプ供試体では，供試体 に加えられたねじり変形は，まずリング接合面でセグメ ントリングE゙うしが滑ることにより吸収される。ささらに 変形が大きくなってリング接合面の滑りだけで吸収でき なくなると，セグメントが回転変形する.

（2）Dタイプ供試体の最終的な破壊はリング接合 面に生じ，七グメントにはリング継手の周辺でクラック が発生するに留まった。このような損傷特性は, 軸力及 び曲げモーメントを受けるシールドトンネルの損傷特性 と一致する。一次覆工のみのシールドトンネルでは, リ ング接合面の滑り変形性能を高めることが，セグメント の回転変形を遅らせ，トンネルの変形性能を高めるため に重要である.

（3）一次覆工だけのシールドトンネルでは，1箇所 のリング接合面に耐力が減少する程度の損傷が生じる と，それ以上の載荷力を受けた場合には，このリング接 合面のみに損傷が集中しやすい。

（4）二次覆工が打設され，一次覆工と二次覆工がジ ベル筋で連結された $\mathrm{E} タ イ フ ゚$ 供試体では, ねじり変形 を受けてもリング接合面の滑りは生じない。これは，ジ ベル筋により, 一次覆工之二次覆工の変形が相互に拘束 されるためである.

（5）Eタイプ供試体では，リング継手や二次覆工 鉄筋の破断より先に，セグメント及び二次覆工がせん断 破壞することにより最終状況に至った。したがって，二
次覆工を有するシールドトンネルがねじりモーメントを 受ける場合には，セグメント及び二次覆工のせん断耐力 を向上することが，耐震設計上重要となる.

（6）一次覆工と二次覆工をジベル筋で連結したシー ルドトンネルの权じり変形性能は, 一次覆工と二次覆工 が相互に変形を拘束する結果，一次覆工のみのシールド トンネルに比べて小さくなる．これは，軸力や曲げを受 けるシールドトンネルで, 二次覆工を設ける方が一次覆 工だけの場合に比べて変形性能が大きいのと大きく異な る.

参 考 文 献

1）川島一彦・杉田秀樹 · 加納尚史 · 大日方尚巳 ·志波由紀 夫：鉄筋コンクリート製シールドトンネルの耐震設計法 に関する研究，土木研究所報告，第 188 号, 1993.5.

2）川島一彦・杉田秀樹 · 加納尚史：正負交番軸方向荷重を 受けるシールドトンネル模型の変形及び破壊特性, 土木 学会論文集, No. 422/I-14, 1990.

3）川島一彦・杉田秀樹・加納尚史：正負交番曲げモーメン トを受けるシールドトンネル模型の変形及び破壊特性, 土木学会論文集, No. 483／I-26, 1994.

4）田村重四郎・伯野元彦・家村浩和 - 竹内幹雄 : 1985 年メ キシコ地震の震害, 土木学会誌, Vol. 71, No. 5, pp. 79 $\sim 85,1986.5$.

5）土木学会, 日本下水道協会共編：シールド工事用標準セ グメント, 1982 年改訂

(1993.10.18 受付)

\section{EXPERIMENTAL INVESTIGATION ON DEFORMATION AND FAILURE MECHANISM OF SHIELD TUNNELS SUBJECTED TO CYCLIC TORSIONAL MOMENT \\ Kazuhiko KAWASHIMA, Hideki SUGITA and Takashi KANOH}

Torsional deformation of shield tunnels is important for seismic design when they are rigidly connected to other structures. Failure mechanism is important for estimating nonlinear hysteretic behavior of shield tunnels subjected to a significant earthquake. There are however few studies on the deformation and failure mechanism of shield tunnels subjected to alternative torsional deformation. A series of loading tests for two shield tunnel specimens subjected to alternative torsional moment was conducted. Presented in this paper are failure mechanism and deformation characteristics of shield tunnels with and without secondary lining. 